Anna Maria Bielak

Uniwersytet im. Adama Mickiewicza w Poznaniu

Wydział Neofilologii

(iD) https://orcid.org/0000-0003-4580-4152
Er(r)go. Teoria-Literatura-Kultura Er(r)go. Theory-Literature-Culture $\mathrm{Nr} / \mathrm{No} .40(1 / 2020)$ pamięć/ideologia/archiwum memory/ideology/archive IS S 2544-3186 https://doi.org/10.31261/errgo.7682

\title{
Życiodajne archiwum Składowiska pamięci w dziele Alberta Cohena
}

\section{The Life-giving Archive. A Stockpile of Memory in Albert Cohen's Work}

Abstract: The present article aims to present a study of several, crucial themes in the writings by Albert Cohen, in the light of Jacques Derrida's concept of the archive. The presence of the experience of the Jewish nation is fixedly important in Cohen's work. In this article, my objective is to prove that Cohen's writing process significantly exceeds the common patterns of thinking about the past or even about the Jewish identity, of which an important component is the continuity of the relationship with the ancestors. Owing to the Derridean concept of the archive, it becomes possible to observe the significance of the past activity and its consequences for the subject's identity.

Keywords: archive, memory, Albert Cohen, fiction

\section{Negacja}

Czytając teksty Cohena, mamy wrażenie, że autor lubuje się w nieskończonym odtwarzaniu unikatowego doświadczenia, które przez fakt jednorazowego zaistnienia raz na zawsze wpisało się w jego tożsamość. Nie ma tutaj reguły, która pomogłaby odsączyć wydarzenia faktyczne od fikcji literackiej. Powtórzenia dotyczą zarówno traumatycznych, rzeczywistych przeżyć, jak również tych związanych z tworzeniem fikcyjnych postaci, które w Cohenowskich powieściach żyją własnym życiem ${ }^{1}$. Powtórzenia wiążą się także w bardzo bezpośredni sposób z żydowską tożsamością ${ }^{2}$ : wiele z odtwarzanych i powtarzanych wydarzeń zasadza się na wspomnieniu doświadczenia - przez Cohena bądź jego przodków i jego

1. Hubert Nyssen, Lecture d'Albert Cohen, Actes Sud, 1981, s. 21.

2. Tożsamością niepozbawioną znamion traumy, która u Cohena zamyka w sobie nie tylko doświadczenie Shoah, lecz także średniowieczne pogromy i ogół doświadczanych przez wieki przez naród wybrany cierpień. Konsekwentnie kontynuowana przez Cohena narracja oparta na bolesnym zbiorowym doświadczeniu traumy odnosi nas w ten sposób także do paradygmatów 
naród w ogóle - antysemityzmu. Zastawiając szczegółowe omówienie zabiegów powtórzeń na później, chciałabym w pierwszej kolejności przyjrzeć się obecnym w tekstach toposom matki, ojca i piwnicy, które z jednej strony oddają delikatne związki utkane przez narratora z jego rodziną jako źródłem pochodzenia, z drugiej wpływają na poczucie tożsamości i przynależności głównego bohatera tekstów powieściowych, Solala.

W swojej pracy poświęconej kwestiom tożsamościowym w pisaniu żydowskim po doświadczeniu Shoah, Clara Lévy wyszczególnia u żydowskich twórców trzy poziomy kultu pochodzenia (le culte de l'origine). Chodzi mianowicie o kult kraju, z którego pisarz pochodzi (pays d’origine), społeczności, z której się wywodzi (communauté d'origine), oraz rodziny (famille d'origine). Niemal wszystkie teksty publikowane przez żydowskich pisarzy po roku 1945, zauważa Lévy, eksponują zagraniczne pochodzenie autora lub jego krewnych ${ }^{3}$. Cohen nie stanowi tutaj wyjątku: na potwierdzenie swojej tezy Lévy cytuje zresztą obszernie rajski opis Kefalonii ${ }^{4}$.

Rodzime Korfu pisarza przeistacza się zatem w powieściach w obraz utraconego raju Kefalonii, do której protagonista Oblubienicy Pana pragnie zabrać swoją kochankę. . Paralelnie eksponowana być musi nieodzowna rola rodziców: to oni bowiem przekazują za sprawą wychowania odpowiednią wiedzę, mającą być punktem wyjścia do autoświadomości. Dziadkowie, ale przede wszystkim figury ojca i matki, będą w tym kontekście według Lévy kluczowe ${ }^{6}$.

Matka Cohena jest niezwykle ważną postacią w tekstach biograficznych. Jej obecność nadaje dramatyzmu tekstowi Carnets $1978^{7}$. Jej ciągłe przywoływanie stanowi odciążający punkt zwrotny dla zbudowanej na antysemickim doświadczeniu dziecka narracji Ô vous, frères humains ${ }^{8}$ : protagonista regularnie przywołuje obraz matki celem ukojenia bólu, wypełnienia druzgocącej pustki matczyną miłością. Prawdziwym hołdem dla matki będzie napisany po jej śmierci tekst Książka

traumy kulturowej, zob. Jeffrey C. Alexander, Toward a Theory of Cultural Trauma, "Cultural Trauma and Collective Identity", University of California Press, California 2004, s. 1-30.

3. Clara Lévy, Écritures de l'identité. Les écrivains juifs après la Shoah, Puf, Paryż 1998, s. 23.

4. Lévy, Écritures..., s. 24.

5. „»Jechać, we dwójkę«, rzekła i położyła głowę na ramieniu wirującego z wolna partnera. »echać dokąd?« zapytał. »Daleko«, westchnęła. »Tam, gdzie się urodziłem, chcesz?« Tam, gdzie się urodził, uśmiechnęła się do upojnej wizji. Jak dobrze, jak dobrze zrobił, że się urodził. »Jechać kiedy, my dwoje? « zapytała. »Zaraz rano, rzekł, samolotem dla nas tylko, a po południu Kefalinia, ty i ja «"; Albert Cohen, Oblubienica Pana, przeł. Andrzej Socha, Wyd. Krakowskie, Kraków 2001, s. 349; co zresztą nigdy nie będzie miało miejsca.

6. Lévy, Écritures..., s. 34.

7. Albert Cohen, Carnets 1978, w: Albert Cohen, Oeuvres, Gallimard, Bibliothèque de la Pléiade, nr 402, Paryż 1993. Tekst nie został wydany w języku polskim.

8. Albert Cohen, Ô vous, frères humains, w: Albert Cohen, Oeuvres..., s. 1044, 1051, 1057, $1067 \mathrm{i}$ inne. 
o mojej matce (fr. Livre de ma mère) (1954). Według Denise Goitein-Galperin', matka jest jedną z trzech, obok pisarstwa i narodu żydowskiego, wielkich miłości Cohena. Co ciekawe, figura matki nie zajmuje szczególnego miejsca w powieściach. Hubert Nyssen ${ }^{10}$ wysuwa tutaj ciekawą hipotezę, zgodnie z którą o tyle obecność matki jest stosunkowo śladowa, a nieliczne, poświęcone jej opisy groteskowe i odstręczające, o ile ukłonem w jej stronę mogą być postaci żydowskich błaznów, Walecznych z Francji, które pomimo licznych, bogato eksponowanych w narracji wad, rozczulają czytelnika swoją nieporadnością i dobrocią serca. Można zatem w pewien sposób, za Nyssenem, odczytać Walecznych jako alegorię ukochanej i wielbionej, zwłaszcza pod koniec życia, kobiety.

Pozostawiając na moment $z$ boku teksty biograficzne, należy zauważyć, że w tekstach tetralogii powieściowej kult społeczności i rodziny ma bardzo burzliwy przebieg: narrator akcentuje stereotypowe żydowskie przywary, czyniąc ze swoich pobratymców niedostosowanych do życia błaznów. W przypadku matki, wspomniany jej obraz jest o tyle dosadniejszy, o ile pozbawiony komicznych aspektów. Należy jednak gwoli ścisłości - i w świetle powyższych rozważań - uzupełnić, że czytelnik nie ma możliwości zaprzyjaźnienia się z figurą tak, jak to przebiega w przypadku Walecznych. Jej obecność ginie w fabule Solala; nawet jej śmierć przebiega w sposób niedostrzegalny. Jeśli możemy stwierdzić, że narrator w pewnym sensie oszczędza ją przed ironią i szyderstwem, to będziemy mieć tutaj na myśli jedynie rozwlekłe objętościowo procesy powtarzania. Krótkie, intensywne opisy poświęcone matce protagonisty (tytułowego Solala), jak zresztą te dotyczące innych, z pewnymi wyjątkami, żydowskich bohaterek, nie pozostawiają bowiem wątpliwości co do ich pejoratywnego charakteru.

Z czego wynika ów negatywny obraz rodzinnych związków? Schaffner, biorąc za punkt wyjścia zarówno odmalowaną pejoratywnie matkę, jak i sugerowane współżycie matki i ojca, które wyobraźnia Solala próbuje odrzucić, powołuje się tutaj na freudowską psychoanalizę. Odrzucenie obrazów rodzicielskiej miłości, obok zanegowania figury matki, miałoby swoje źródło w impulsywnym pragnieniu odrzucenia tradycji żydowskiej ${ }^{11}$. W konsekwencji poczucie przynależności i chęć utożsamienia się z pochodzeniem i domem rodzinnym pozostaje $\mathrm{w}$ powieściach tetralogii, a szczególnie w Solalu (postawa protagonisty zostanie w kolejnych tekstach znacznie zmodyfikowana) bardzo zachwiana. Niemniej jednak, co dla naszej analizy szczególnie ważne, podejmowane przez bohatera próby stworzenia siebie na nowo, bez udziału przodków i przy kompletnym za-

9. Denise Goitein-Galperin, Visage de mon peuple, essai sur Albert Cohen, Nizet, 1982, s. 27.

10. Nyssen, Lecture..., s. 37. Dowodem na poparcie tej hipotezy byłby fakt, że tekst Les Valeureux, opisujący losy, walecznych został przez pisarza zadedykowany właśnie matce.

11. Alain Schaffner, Le goût de l'absolu, Honoré Champion, Paryż 1999, s. 216. 
negowaniu roli swojej przeszłości i swoich bliskich spalą wszystkie, jak się o tym jeszcze później przekonamy, na panewce. Potrzeba negacji stanowi sama w sobie dowód na nieredukowalną trudność towarzyszącą zabiegom mającym na celu odsączenie tożsamości od środowiska rodzinnego, którym się karmi.

\section{Nakaz powrotu}

Matka nie jest niczym innym jak znakiem tożsamości, z którym narrator bądź protagonista czuje się związany. Zakreśla wirtualne miejsce, do którego pragnie wrócić narrator tekstów biograficznych albo nawet zawiera w sobie - w porządku fikcyjnym, jeśli przyjmiemy hipotezę Nyssena - elementy składowe przeszłości uformowane w sylwetki zabawnych Walecznych. Wyznacza poczucie przynależności i zakreśla nieosiągalne miejsce powrotu.

Do ukształtowanego na świadomości i wiedzy o przodkach poczucia przynależności odwołuje w pewnym sensie tekst Derridy, Gorączka archiwów. Czym jest tytułowe archiwum? To pojęcie, jak zauważa sam autor, stosunkowo trudne ${ }^{12}$, a my w naszej pracy skupimy się na kilku jego najważniejszych dla nas aspektach, to jest konkretnie na porządkach nomologicznych i topologicznych, w obrębie których funkcjonuje, na figurze archonta, na otchłaniach i na powierzchniowych śladach archiwum, w końcu na jego tytułowej "gorączce".

Na wstępie swojej pracy Derrida wiąże pojęcie archiwum z greckim arche, oznaczającym zarówno początek, jak i nakaz/rozkaz ${ }^{13}$. Konstytuują się dwa porządki: topologiczny źródła/miejsca i nomologiczny, związany z nakazem. Archiwum oferuje więcej niż dostęp podmiotu do wiedzy, która owocuje świadomością siebie i umożliwia utożsamienie się z konkretną myślą, grupą czy nawet miejscem. Nomologiczna zasada nakazu ${ }^{14}$, porządek rozkazujący (jussique), niemal natychmiast odsyła nas do krzywdzącej figury ojca/prawa. I tak, w myśl koncepcji Derridy, archiwum wiąże się nie tylko z samą psychoanalizą i figurą ojca, lecz także z jej (psychoanalizy) „ojcem”, Zygmuntem Freudem, w końcu z ojcem ojca. Nie wcho-

12. „Nic nie jest zatem dziś bardziej chaotyczne i bardziej niepokojące niż pojęcie zarchiwizowane w słowie "archiwum «"; Jacques Derrida, Gorączka archiwów, przeł. Jakub Momro, Instytut Badań Literackich PAN, seria wyd. Nowa Humanistyka, Warszawa 2016, s. 134.

13. Derrida, Goraczka..., s. 9-10.

14. Pierre Nora mówi wręcz o wewnętrznym nakazie-imperatywie tworzenia archiwum: "Imperatywem naszej epoki jest nie tylko zachowywanie wszystkiego, ocalanie każdej oznaki pamięci - nawet jeśli nie jesteśmy pewni, jakiego rodzaju pamięć oznaczamy - ale również tworzenie archiwów.” Pierre Nora, Między pamięcią a historia: Les lieux de Mémoire, „Tytuł Roboczy. Archiwum", nr 2, 2009, s. 7, cyt. za: Bernadetta Wilk, Archiwum miejscem pamięci o ludziach nauki i kultury, „Zarządzanie w Kulturze”, nr 18, z. 2, 2017, s. 195-217. 
dząc głębiej w raczej zawiły wywód, przyjrzyjmy się, w jaki sposób figura ojca, funkcjonuje w powieści Solal.

Kiedy mowa o figurze ojca, to w jego przypadku wszystko przebiega odwrotnie niż w przypadku matki: pomijany w tekstach biograficznych, staje się bardzo istotną figurą narracji tetralogii, zwłaszcza Solala. Gamaliel, ojciec tytułowego bohatera i jednocześnie najważniejsza postać ojcowska całego cyklu powieściowego, jest figurą dostojną, poważną, skupioną i oszczędną w słowach, która pojawia się zazwyczaj w towarzystwie innego dostojnika. Pierwszy raz dowiadujemy się o nim za sprawą Saltiela:

Mój szwagier rabin prawi mi kazania, bo się golę; utrzymuje, że pokazywanie wygolonej twarzy jest czymś bezwstydnym. A ja mam duszę tak samo czystą jak ty, o najwspanialszy Gamalielu Solal, o, najdostojnieszy naczelny rabinie Wspólnoty Siedmiu Wysp Jońskich z siedzibą na Kefalinii! (S: 12).

Już z tej krótkiej zapowiedzi postaci miarkować możemy o jego roli i jego wpływie na społeczność żydowską. Saltiel przypomina sobie zresztą o Gamalielu w kontekście przestrzegania zasad ortodoksyjnego prawa żydowskiego. Rabin Gamaliel staje się nośnikiem, symbolizuje albo wręcz ucieleśnia prawo, a postaci myśląc o prawie automatycznie odwołują się do Gamaliela.

Relacja, którą Gamaliel utrzymuje z synem, jest bardzo formalna:

Powiedział [Gwoździojad] Solalowi, że jego czcigodny pan ojciec czeka na niego.

Gamaliel Solal odniósł się do syna tak jak zwykle: poprosił go, chyba z myślą o koledze z Bagdadu, aby odczytał pracę egzegetyczną, jaką był mu zadał. [...] Solal posłusznie odczytał, co należało, obojętnym głosem (S: 20).

Gamaliel jest tym, który kieruje i rozporządza - dopóki jest to możliwe - losem syna. Symbolicznym momentem odwrócenia tego porządku będzie bar micwa Solala: zgodnie z prawem żydowskim w momencie osiągnięcia religijnej pełnoletniości syn staje się podmiotem prawa i przejmuje ciążącą wcześniej na ojcu odpowiedzialność za swoje czyny ${ }^{15}$. W czasie bar micwy Gamaliel wygłasza rozczarowująco krótkie - a mimo to jest to jedna z jego dłuższych wypowiedzi przemówienie, zawierające istotne wskazówki dla odpowiedniego prowadzenia się w życiu dorostym ${ }^{16}$. Gdyby Solal zdecydował się zastosować do porady, która okazała się raczej przepowiednią - dodajmy, że Gamaliel przestrzega syna przede wszystkim przed zwodniczym wpływem kobiecego piękna - na pewno pomogło-

15. Zob. Ivan G. Marcus, The Jewish Life Cycle: Rites of Passage from Biblical to Modern Times, University of Washington Press, 2004.

16. Chodzi oczywiście o dorosłość religijną, to jest w tradycji żydowskiej wiek 13 lat. 
by to w uniknięciu wielu katastrof, na których zresztą opiera się dalsza narracja. Gamaliel jednak nie przekonuje go, nie omawia podjętego tematu - nie taka jest jego rola. Funkcjonuje raczej jako zasada, krótki nakaz, który powinien zostać wypełniony bez wdawania się w szczegóły. Sama jego obecność wyznacza zatem ramy prawa żydowskiego (stojącego w opozycji do porządku Zachodu i kultu piękna), któremu należy się podporządkować. W ten właśnie sposób rabin zakreśla także granice (żydowskiej) tożsamości, która poprzez prawo się kształtuje. Odrzucenie Gamaliela/prawa/żydowskości na dalszym etapie narracji zaowocuje nieznośną pustką, którą Solal będzie mógł wypełnić jedynie poprzez ponowny zwrot w stronę ojca. Pustka wiąże się z bolesnym brakiem dostępu do archiwum, którego instytucjonalna realizacja zostaje zachwiana tam, gdzie podaje się w wątpliwość konsygnacyjną władzę archonta ${ }^{17}$.

Stojąc na straży żydowskiego prawa, Gamaliel jest zatem punktem zwrotnym, bramą, miejscem, do którego Solal musi powrócić jak do siebie. Odtwarza się pewien cykl: folgując swoim „zachodnim” upodobaniom, Solal walczy z ojcem/ prawem, aby kolejno zwrócić się w jego stronę. Gamaliel, jego rabiniczna wiedza i jego dbałość o księgi nosi tutaj znamiona figury archonta:

W obywatelach, dzierżących i oznaczających w ten sposób władzę polityczną, dostrzegano uprawnionych do tworzenia bądź reprezentowania prawa. Biorąc pod uwagę ich publicznie uznawaną władzę rządzenia, to u nich, w ich miejscu, będącym ich domem (domem prywatnym, rodzinnym i wynajmowanym), zostają złożone oficjalne dokumenty. Archonci są przede wszystkim strażnikami dokumentów ${ }^{18}$.

Obecność Gamaliela wyznacza tory fabuły i wpływa na postaci: Gwoździojad wyraża się o nim z szacunkiem, Saltiel, jak widzieliśmy wyżej, próbuje narzucić sobie bardziej rygorystyczne postępowanie. Powaga, którą wokół siebie roztacza, stanowi zatem przeciwwagę dla komicznych wątków i groteskowych opisów. Gamaliel funkcjonuje jako znak, który zamyka w sobie ogrom rabinicznej tradycji. Jest nie tylko strażnikiem Prawa i dbałości o to, aby spuściznę prawa scedować na kolejne pokolenie - aby przekazać synowi pismo i jego podstawę, to jest w pewnym sensie Biblię, jakby powiedział Derrida ${ }^{19}$ - ale także samym dokumentem, to jest czymś, co poświadcza oddziaływanie prawa, dokumentem, który, jak mówi Derrida, wyraża, przywotuje i odwotuje się do prawa.

Ów znak jest w pewnym sensie niedostępny: to nie do końca czytelny dokument, który, chociaż wskazuje, nie daje odbiorcy satysfakcjonującej i skończonej wiedzy. Nie ma w nim treści, które podpowiadałyby, jak „nauczyć się żyć”, przywołując

17. Derrida, Goraczka..., s. 12-13.

18. Derrida, Gorączka..., s. 10-11.

19. Derrida, Gorączka..., s. 37. 
Derridiańskie rozważania otwierające Widma Marksa ${ }^{20}$, nawet jeśli wydaje się, że właśnie tego rodzaju wskazówek szukać u Gamaliela musi Solal w momentach rozterki i zwątpienia; emituje co najwyżej suche, nie zawsze zrozumiałe nakazy.

\section{Piwnica albo powrót do archiwum}

Efektem końcowym odtwarzania cyklu powrotu do ojca/prawa w Solalu będzie zakup zamku w Saint-Germain. To punkt kulminacyjny, w którym Solal nie jest w stanie dłużej znieść swojego zachodniego - niemniej pełnego sukcesów - życia i zwraca się do ojca:

Poszedłem do kolan paść mojemu panu ojcu i ten miłosierny człowiek przebaczył mi. Przykazał, bym urządził tajemną siedzibę w mym europejskim domostwie. Mądry jest i rozumie, że mam obowiązek kontynuować mój orientalny żywot. Sprowadziłem Solalów, tych z Kefalinii i zewsząd. Prawdziwe biblijne miasto mrowi się w podziemiach domostwa Jego Ekscelencji ${ }^{21}$.

Tajemna siedziba mieści się w średniowiecznej piwnicy renesansowego zamku, który protagonista zakupi za pieniądze młodej małżonki. Będąc u szczytu błyskotliwej kariery politycznej, z piękną Aude u boku i z silnym zapleczem zawodowym (zapewnionym przez ojca Aude), Solal decyduje się zwrócić w stronę przeszłości, odnaleźć swojego ojca i poprosić go o wybaczenie.

Przeszłość wraca zatem do protagonisty niczym bumerang i nakazuje mu, po raz kolejny, być posłusznym. Jej cień osadzi się w piwnicach starego zamku, który odzwierciedla kształt tożsamości Solala ${ }^{22}$. To, co najbardziej osobiste i jednocześnie najbardziej wstydliwe - żydowscy krewni, za których wstydzić się musi w ministerstwie - zostaje przez niego umieszczone w piwnicy. Postaci, które Solal lokuje w podziemiach swojej zachodniej rezydencji, na obrzeżach swojego zachodniego życia, są niezwykle ważne, ponieważ noszą w sobie brzemię przeszłości, stanowiąc tym samym świadectwo - czy może dokument - rzeczywistego pochodzenia Solala.

Bohater jest więc jedynie wykonawcą prawa, który realizuje sformułowany przez ojca nakaz. Wydaje się jednak, że rola Gamaliela jest tutaj także do pewnego stopnia ograniczona, że cienie przeszłości snujące się po świadomości protagonisty nie dadzą mu spokoju, dopóki ten nie znajdzie dla nich miejsca:

20. Jacques Derrida, Widma Marksa, przeł. Tomasz Załuski, PWN, Warszawa 2016, s. 11.

21. Albert Cohen, Solal, przeł. Andrzej Socha, Wyd. Noir sur blanc, Warszawa 2007, s. 259-260.

22. Philippe Zard zwraca także uwagę, że zamek może symbolizować zachodnią tożsamość, zob. « Dans ma demeure d'Europe ». La cave de Saint-Germain et l'identité spirituelle de l'Europe, „Cahiers Albert Cohen: Visions du sacré”, nr 4, 1994, s. 85. 
Aby mogły być w ten sposób strzeżone, aby mogły podlegać jurysdykcji tego wyrażania prawa, dokumenty potrzebują zarazem strażnika oraz umiejscowienia. Archiwa, nawet w swym stróżowaniu bądź w swej tradycji hermeneutycznej, nie funkcjonują bez podstawy ani bez siedziby ${ }^{23}$.

Dokumenty, podobnie jak krewni Solala, potrzebują swojego miejsca spoczynku. Żydowscy wujowie i kuzynowie muszą mieć gdzie się osiedlić i odpocząć; dokumenty potrzebują umiejscowienia, aby zaistnieć. Jak wykazuje Derrida, archiwa muszą zostać uwięzione, wręcz „udomowione”24. Cóż innego robi Solal, sprowadzając swoich żydowskich krewnych, całą swoją przeszłość, całe swoje dzieciństwo z odległej greckiej wyspy do piwnicy europejskiego zamku, jeśli nie stara się właśnie podporządkować jej sobie, udomowić i przechować w otchłaniach budowli w największej tajemnicy przed światem? Co równie ważne, w istocie Solal pod wpływem Gamaliela nie nawiązuje relacji ze swoją rodziną, lecz z przeszłością, na którą składają się żywe zjawy, z najstarszym - tak starym, że każącym się przemieszczać w trumnie - Majmonem na czele, którego pojawianie się w narracji Nyssen utożsamia ze zjawą śmierci ${ }^{25}$.

Zamknięta w świadomości Solala, symbolicznie w piwnicach jego zamku, przeszłość jest zupełnie niedostępna dla młodej małżonki Solala, Aude. Dla niej przeszłość męża jest zawodzeniem umarłych, głosem spod ziemi ${ }^{26}$, dla naszego protagonisty przeszłość zaś przekształca się ni mniej ni więcej jak w spersonalizowane archiwum. Z perspektywy topologicznej archiwum stanowi miejsce pracy świadomości, schronienie cierpiącego narodu, którego trauma, chociaż możemy obserwować jej poszczególne wcielenia, funkcjonuje jako doświadczenie zbiorowe i zarazem jako składowa indywidualnej pamięci. Z perspektywy nomologicznej prawa - bo w żadnym innym miejscu narracji Solal nie podlega tak bezwarunkowo eksplicytnie woli ojca - archiwum staje się jego, prawa, podziemnym królestwem.

Archiwum Solala to miejsce ukryte i zamknięte dla zewnętrza. Wtargnięcie obcej osoby, nawet jeśli zaplanowane, natychmiast je unicestwia: wtajemniczona małżonka Solala nie przejdzie inicjacji i w konsekwencji Solal odeśle swoich krewnych. Nawiązując jednak znowu do Derridy, w swoim szkicu dekonstrukcjonista zwraca również uwagę na przejście od sfery prywatnej do publicznej ${ }^{27}$. Jeśli chodzi o Solala, to bohater najpierw czyni ze swojej żydowskiej przeszłości orientalny relikt, oddając mu przy tym należytą cześć, a następnie wystawia go na ogląd

23. Derrida, Gorączka..., s. 11.

24. Derrida, Gorączka..., s. 11.

25. Nyssen, Lecture..., s. 39.

26. Istotnie bohaterka dowiaduje się o sprowadzonych „gościach”, słysząc najpierw ich śpiewy i poszukując źródła głosu.

27. Zob. Derrida, Goraczka..., s. 11. 
zachodniej, protestanckiej żony. Nie ma tutaj znaczenia intencja: Aude zstępuje do piwnicy pełna dobrej woli, nadziei, kierowana romantyczną wizją odnalezienia żydowskich proroków. Wszystko to rozpływa się jednak przy pierwszym kontakcie z Gamalielem; poznanie obcego archiwum okaże się dla niej niemożliwe. Jej doświadczenie możemy porównać do wizyty w muzeum, w którym zamiast pięknych obrazów napotykamy dziwaczne eksponaty, które w dodatku okazują się żywe, równie żywe co przerażające.

\section{Egzerga albo na powierzchni}

Archiwum nie rozpływa się jednak wraz z symbolicznym unicestwieniem jego dokumentacji, a więc w przypadku Solala - odesłaniem krewnych pod wpływem żony. W tym miejscu chcielibyśmy zastanowić się nad samą powierzchnią archiwum, albo nad tym, jakie zewnętrzne symptomy odsyłają do jego wnętrza. U Derridy archiwum ma związek z drukiem, który, co bardzo ważne, pozwala się zredukować. W jaki sposób przebiega redukcja? Gdy zagłębiamy się we fragment zatytułowany Egzerga, przed oczami staje nam moneta ze swoją maleńką inskrypcją, swoistym podpisem, który odnosząc się do archiwum, jednocześnie je minimalizuje, ogranicza do minimalnej jednostki. Ta zdolność archiwum do ekonomii funkcjonuje nie tylko w obrębie materialnego tekstu, literalnego za pomocą liter - zapisu na przedmiocie, ale także, idąc jeszcze dalej, ciała. W ten sposób Derridiańską egzergą będzie określone także obrzezanie.

Obrzezanie jako inskrypcja znaczy konkretne miejsce. I nie chodzi tutaj o miejsce, które znaczy, ale o wskazanie na konkretne, to jest zawsze to samo miejsce na skórze, tak jak druk znaczy i wskazuje miejsce na papierze. W tym sensie możemy odczytać je jako egzergę archiwum, widoczną na zewnątrz, na samej powierzchni ciała. Ciało Solala również zostało - w świetle kluczowej roli ojca/prawa nie możemy mieć co do tego wątpliwości - raz na zawsze naznaczone. Ukryta w tym ciele świadomość przechowuje pokłady wykuwanych na pamięć pod wpływem ojca/prawa dokumentów, które następnie umiejscawia on, wraz z widmami przeszłości, w archiwum. Obrzezanie jest jednak egzergą krzywdzącą - redukuje wielość i różnorodność do jednego miejsca i jednego tematu. I tak na przykład kochanki Solala widzieć będą mogły jedynie zewnętrzną różnicę, a nigdy nie będą w stanie sięgnąć głębiej, do wewnątrz, i odczytać autentycznego, źródłowego dokumentu.

Niemniej, Derridiańska refleksja na temat druku jest jedynie punktem wyjścia do rozważań na temat popędu śmierci/zniszczenia. Za ojcem psychoanalizy, dekonstrukcjonista zastanawia się tutaj, czy zadrukowany papier nie pójdzie 
na marne albo co zrobić, by tak się nie stało. Wracamy zatem do Cohenowskiej [nad]produkcji tekstu, która również szuka swojego uzasadnienia.

\section{Obsesja powtarzania i goracczka archiwum}

O Cohenie wiemy, że swoje powieści dyktował. Jego przyjemność zaklasyfikować możemy jako czysto retoryczną, słowną ekstazę o profetycznym zabarwieniu. Pisarz nie zakładał ani błędu, ani nadmiaru. Przyjemność czerpał nie z poprawiania, ale z dodawania do skryptu kolejnych fragmentów. Deklarował przy tym, że jego pisanie ma stanowić dowód na to, że zasługuje na miłość, która go w życiu spotyka. Ów nadmiar był więc dla niego w jakimś stopniu komplementarny do tego, czym był. Powyższe spostrzeżenia odbijają się na pisarstwie w sposób dwojaki: po pierwsze zaznaczają nieskończoną potrzebę produkowania słów, dobudowywania i rozbudowywania partii tekstów, po drugie odwołują do zabiegów powtarzania.

Zaczynając od produkcji, nie można tutaj pominąć faktu, że niektóre z Cohenowskich tekstów „pierwotnych”, żeby odróżnić je w ten sposób od ich kolejnych form, otrzymały szansę ponownego zaistnienia, czasami wiele lat później, w obszerniejszej wersji i pod nowym tytułem. Le jour de mes dix ans, bardzo ważny biograficznie tekst, stanowiący studium doświadczonej przez dziecko antysemickiej traumy - rozrasta się w O vous, frères humains. Chant de mort jest punktem wyjścia do opublikowanej dziesięć lat później Livre de ma mère ${ }^{28}$. Oblubienica Pana, która zasługiwałaby pewnie na osobne omówienie, w pierwotnej przedwojennej wersji okazała się zbyt długa, aby wydawca mógł ją zaakceptować. O ile została skrócona (autor wyciął z niej wydanego w 1938 roku Gwoździojada), o tyle po wojnie została ponownie przepracowana. Mamy zatem do czynienia $\mathrm{z}$ wiecznie otwartym procesem twórczym, który sam autor określił mianem "chwalebnie rakotwórczej proliferacji” ("prolifération glorieusement cancéreuse«).

Jeśli chodzi o zabiegi powtarzania, wyszczególnić można na pewno kilka poziomów, które ograniczymy tutaj do dwóch: tekstów prozy biograficznej i powieściowej. Niezależnie od tego, we wszystkich tekstach powtórzenia wpływają niezmiennie zarówno na treść, jak i na styl: Laurence Audéoud analizuje tutaj na przykład powtórzenia biblijne obecne w zbiorze poezji Paroles juives oraz w biograficznym tekście Carnets $1978^{29}$.

Warto zauważyć, że w tekstach biograficznych elementem regularnie powracającym w narracji jest często trauma, dotkliwe przeżycie bądź strata. W Ô vous,

28. Schaffner, Le goût..., s. 15.

29. Laurence Audéoud, Paroles de prophètes. Répétitions bibliques dans Paroles Juives et Carnets 1978 d'Albert Cohen, Peter Lang, Bern 2007. 
frères humains powraca regularnie, niczym refren, głos ulicznego sprzedawcy. Poszczególne słowa i zdania, raz zasłyszane/zapisane, odtwarzają się ciągle na nowo. Ów zaczerpnięty z życia epizod okazuje się, poprzez nieustanne do niego powracanie, jednym z najdotkliwszych wspomnień. Wskazując na żydowskość dziesięcioletniego chłopca, wyłapując go z tłumu gapowiczów po to tylko, aby go upokorzyć, sprzedawca stał się dla pisarza prawdziwym uosobieniem antysemityzmu. Jego głos odbija się echem nie tylko w świadomości narratora Ô vous..., lecz także w innych tekstach.

Nieco inaczej dzieje się w przypadku tekstów prozy powieściowej. Kolejni bohaterowie świata przedstawionego albo prześcigają się w retoryce, albo po prostu oddają się bez reszty przyjemności mówienia, czy to w postaci monologu, czy wewnętrznego strumienia świadomości. Tworzenie słów w nadmiarze pochłania narratora, Solala, Gwoździojada, Rachelę czy innych bohaterów fikcji.

Zapewne nadmiar ten można różnie tłumaczyć. Być może służy on zamaskowaniu - zgadzałoby się to w przypadku wszystkich wymienionych wyżej postaci i narratora - uwierającej, odczuwanej w momentach melancholii, pustki. „Być może jest tak, jak mówi Michel Foucault, że zbliżanie się do śmierci, jej władczy gest, którym wkrada się do ludzkiej pamięci, drąży w istnieniu i teraźniejszości pustkę, z wnętrza której i ku której kierujemy swe słowa"30. Tak jak Cohenowski narrator tekstów biograficznych nie może, a być może nie chce, zapomnieć, tak jednak w przypadku tekstów powieściowych powtarzają się także komiczne elementy: powtarzanie i samo mówienie staje się grą, która ma na chwilę zabawić, pomóc pogrążyć się w przyjemności słowa i właśnie zapomnieć o tym, co istnieje poza nim.

Derrida tłumaczy, analizując przypadek Freuda, że nadmiar słów zwraca się w stronę nowego: zapisywanie ma prowadzić do realizacji nowego projektu, który swoim zaistnieniem sprawi, że inwestycja w tusz i papier (druk, który u Derridy jest także archiwizacją) „stanie się opłacalna”31. Nowe odkrycie musi przy tym zostać nie tylko ogłoszone: musi też zostać wydrukowane, to jest zarchiwizowa$n e^{32}$. Umieszczenie w przestrzeni archiwum, uczynienie go jego częścią, ustanowi projekt jako archiwalną wiedzę, z której kolejno będziemy mogli czerpać.

Cohen swoje książki wygłasza (dyktuje), tworzy słowa i narracje, ale dopiero ich spisanie, przeniesienie do przestrzeni archiwum za pomocą druku, nadaje im pełną wartość. Powracanie do treści raz spisanej prowokuje wrażenie cyklicznego powrotu, wiecznego nurzania się w znakach przeszłości. Jednocześnie

30. Michel Foucault, Język bez końca, przeł. Michał Paweł Markowski, w: Powiedziane, napisane. Szaleństwo i literatura, Aletheia, Warszawa 1999, s. 67.

31. Derrida, Gorączka..., s. 19.

32. Derrida, Gorączka..., s. 19. 
zakreśla drogę ucieczki w przyszłość, która ustanowić się musi na przeszłości, w porozumieniu z jej znakami. W Cohenowskich Carnets 1978 czytamy: „J'ai quatre-vingt-deux ans et je vais bientôt mourir. Vite me redire, stupidement souriant, me redire le temps de mon enfance, vite avant la fin de moi et de mes souvenirs"33. Autor śpieszy się, aby spisać swoje wspomnienia jeszcze przed śmiercią, pisze zatem w perspektywie przyszłej śmierci, w strachu przed nią, który oznacza tutaj strach przed zapomnieniem, przed utraceniem swojego dzieciństwa i swojej przeszłości.

Sam strach przed śmiercią nie jest jednak jeszcze równoznaczny ze stratą czy zniszczeniem. Popęd straty, jak mówi Derrida,

działa zawsze w milczeniu, nie pozostawia nigdy swojego archiwum. Popęd z góry niszczy swoje własne archiwum, jak gdyby istniała w nim naprawdę szczególna motywacja do właściwego mu ruchu. Popęd pracuje, aby zniszczyć archiwum, pod warunkiem, lecz również w celu wymazania swych ,własnych” śladów $[. . .]^{34}$.

Popęd straty i śmierci umożliwia i zarazem niesie ryzyko unicestwienia archiwum. Cohen nie tyle pragnie zniszczyć, ile uwiecznić swoje archiwum i swoją przeszłość. Ruch w stronę straty/śmierci, który objawia się jej odtwarzaniem/ zapisywaniem, jest w rzeczywistości zwróceniem się w stronę życia. Przeszłość w pisarstwie Cohena jest ciągle żywa, nieredukowalna do powierzchniowych znaków. Jej elementy wpisują się, jak zauważa Lévy, w kontinuum historii żydowskiej ${ }^{35}$. Cohen, odtwarzając swoja przeszłość, powołuje się na doświadczenie narodu żydowskiego sięgające najdawniejszych czasów ${ }^{36}$. Po drodze wywiązuje się jednak szereg trudności, związanych zarówno z definicją, czym owe archiwum rzeczywiście jest, jak i z jego palącą potrzebą:

Kłopot $\mathrm{z}$ archiwum (trouble d'archive) wynika $\mathrm{z}$ gorączki archiwum (mal d'archive). Brakuje nam archiwum. [...] To paląca namiętność. To, co nigdy się nie zatrzymuje, coś nieskończonego, to szukanie archiwum tam, gdzie się ono ukrywa. To pogoń za nim, nawet jeśli jest go zbyt dużo, tam, gdzie coś w nim samym się anarchiwizuje. To doświadczenie

33. „Mam osiemdziesiąt dwa lata i wkrótce umrę. A więc szybko, powiedzieć sobie jeszcze raz, z głupim uśmiechem na twarzy, opowiedzieć sobie jeszcze raz czasy dzieciństwa, szybko, zanim nadejdzie koniec, mój i moich wspomnień” (przeł. A.M.B); Albert Cohen, Oeuvres..., s. 1115.

34. Derrida, Gorączka..., s. 22.

35. Lévy, Écritures..., s. 37.

36. Obcowanie negatywne z przeszłością zakreśla na przykład narracja Racheli w Oblubienicy Pana: „[...] Ale przede wszystkim palili nas na stosach! We wszystkich niemieckich miastach, w Wissemburgu, w Magdeburgu, w Arnstadt, w Koblencji, w Sinzig, w Erfurcie! Byli dumni mianując się przysmażaczami Żydów! [...] Palili nas w trzynastym wieku! Będą nas palić w dwudziestym!". Cohen, Oblubienica..., s. 446. 
natrętnego, powtarzającego się i nostalgicznego pragnienia, nieustającego pragnienia powrotu do źródła, bolesna tęsknota za domem, nostalgia za powrotem do najbardziej archaicznego miejsca absolutnego początku ${ }^{37}$.

W archiwum mamy do czynienia z obezwładniającym żywiołem. Przy okazji sumowania tez i akcentowania kluczowej roli Freuda, który według Derridy umożliwił myślenie o archiwum w ogóle, dekonstrukcjonista zauważa, że archiwum „nie da się zredukować do pamięci: ani do pamięci jako świadomej rezerwy, ani do pamięci jako aktu przypominania czy wspominania"38. Nie jest ono zatem otwartym źródłem, z którego można bezwarunkowo czerpać, wspominając. Wyraża jednak pragnienie powrotu, niezmiennie natrętne oraz powtarzające się, które nie są obce pisarstwu Alberta Cohena. Na przykładzie analizy figur ojca i matki w prozie powieściowej Cohena widzieliśmy, w jaki sposób zanegowana przeszłość (matka, która przez Lewy-Bertaut ${ }^{39}$ jest utożsamiana $z$ bezpieczną przestrzenią) jest kolejno egzekwowana przez prawo/ojca. Kreacja postaci Solala, paralelnie do działań pisarza, poddaje się popędom życia i śmierci albo życia poprzez nawiązanie relacji ze śmiercią/przeszłością. W Cohenowskiej piwnicy pulsuje życie naznaczone traumą, doświadczeniem antysemickiej zbrodni i lękiem przed śmiercią; pulsuje w niej jednak także pragnienie życia, szczególnie widoczne, kiedy pod uwagę weźmiemy ogół Cohenowskich tekstów. Tym samym Cohenowskie archiwum funkcjonuje nie tyle jako repozytorium wspomnień, w których wiecznie odtwarza się i różnicuje raz doświadczona przeszłość.

W jaki sposób możemy poddać refleksji to nieuchronne powtórzenie, ogólne powtórzenie w jego związku z pamięcią i archiwum? Nietrudno zinterpretować konieczność takiego związku, przynajmniej, kiedy łączymy archiwum - bo zwykle jesteśmy skłonni to robić - z powtórzeniem oraz powtórzeniem przeszłości. Chodzi tu jednak o przyszłość i o archiwum jako nieredukowalne doświadczenie przyszłości ${ }^{40}$.

Archiwum nie jest doświadczeniem przeszłości, mówi Derrida, ale przyszłości. Jest tym samym przeszłością aktualnie odczuwaną i żywo obecną, mającą aktywny udział w indywidualnym konstruowaniu przyszłości przez podmiot. Z pozoru niedostępne a dla osób trzecich wręcz hermetyczne, archiwum funkcjonuje, i to także pisarstwo Cohena doskonale obrazuje, jako życiodajne źródło. Impuls, który z niego wypływa, który rodzi się poprzez bliskie, cza-

37. Derrida, Gorączka..., s. 134.

38. Derrida, Goraczka..., s. 135.

39. Évelyne Lewy-Bertaut, Albert Cohen mythobiographe, Ellug, Grenoble 2001, s. 150.

40. Derrida, Goraczka..., s. 103. 
sami bolesne, obcowanie z przeszłością, jest impulsem nie tylko odtwarzania, lecz także stwarzania, tworzenia nowego na gruncie zarchiwizowanego. Jest też źródłem pisania - tworzenia poprzez pismo - które musi nieustannie, autotelicznie poświadczać sens swego zaistnienia. 